\title{
Postcolonial Re-imaginations: Interrogating Archival Space in Indo-European Encounters
}

\author{
Gladson Jathanna
}

\begin{abstract}
Die Geschichtsschreibung der christlichen Mission in Indien wird von postkolonial arbeitenden Gelehrten in den letzten Jahrzehnten zunehmend kritisch hinterfragt. Postkolonialismus als Theorie stellt die elitäre und eurozentrische Geschichtsschreibung des Christentums in Indien in Frage. Gleichzeitig betont der Feminismus die Genderkonstruktion der christlichen Mission in Kolonien wie Indien und wertet kritisch die missionarischen Interessen an Frauenfragen und die Gründung der Frauenmission für Frauen aus. Solche Ansätze helfen, die Darstellung indischer Frauen im Schrifttum der Missionare zu problematisieren. Die methodischen Ansätze sind jedoch selbst problematisierungsbedürftig. Es scheint eine Tendenz unter den postkolonial-feministischen Gelehrten zu geben, Missionarinnen und ihre Aktivitäten als bloße Nachahmung männlich-zentrierter westlicher Missionsorganisationen anzusehen. Eine tiefergehende Auseinandersetzung mit den Missionsarchiven nötigt dazu, solche Zuschreibungen in Frage zu stellen. Eine neue Perspektive auf die Missionsarchive könnte uns zeigen, dass es nicht nur ein Verständnis der Aktivitäten von Missionarinnen gibt, sondern dass es mehrere Bedeutungen undVerständnisse gibt. Der Tenor dieses Artikels ist, dass eine postkoloniale Untersuchung eines Archivraums, genauer: von Missionsarchiven, uns eine neuartige methodische Verortung in der lokalen Kirchengeschichte ermöglichen könnte, die einst ausschließlich als christliche Missionsgeschichte angesehen wurde.
\end{abstract}

Christian history in the third millennium must take seriously into consideration the attempts made by secular historians, anthropologists, and sociologists and acknowledge that these attempts enable Christian historians and [...] Christian theologians to reread history and highlight neglected and forgotten events ${ }^{1}$

1 A. Mathias Mundadan, The Changing Task of Christian History: A View at the Onset of the Third Millennium, in: Wilbert R. Shenk (ed.), Enlarging the Story: Perspectives on Writing World Christian History, New York 2002, 22-53, 47. 
Mathias Mundadan, a well-known historian of Christianity in India, highlights the need for a historiography of Indian Christianity to adopt new methodological standpoints beyond the limited understanding of Christian history as the story of Christian triumphalism in a 'non-Christian' world. The last few decades did see a larger methodological shift in the historiography of Christianity, or more precisely, the historiography of Christian Missions in India. A major methodological shift could be traced back to the 'post-colonial' historians who started out by creatively combining theoretical and methodological tools provided by Michel Foucault, Edward Said and Homi Bhabha, among others, in order to challenge what they perceived as elite and Eurocentric historiography of Christianity in India. Not only the historians of Christianity but also researchers from other disciplines got involved in such explorations. ${ }^{2}$ These works highlighted the colonial nature of Christian missions in India under the pretext, "colonising mission."

The feminist concerns lead many researchers interested in Christian Missions in India to take postcolonial methodology to a wider level. Such works emphasize the gender notion of Christian missions in colonies like India and critically evaluate missionary interests in women's questions and establishment of women's mission for women. ${ }^{3}$ They identify the gendered aspect of Christian mission and see the Christianity of European missions as "muscular Christianity," ${ }^{\prime 4}$ and highlight the patriarchal worldview of the missionaries which reinforced the already existing gender-binaries in the colonies. These approaches help us to problematise the representation of Indian women in the missionary writings. However, such methodological approaches are themselves in need of problematisation. There seems to be a common tendency at work among the postcolonial feminist scholars to emblem the missionary women and their activities as mere 'mimics' of male-centred Western missionary agencies. A deeper engagement with the mission archives forces us to challenge such emblems. Revisiting the Mission archives could show us that there is not just one level of understanding of women missionaries' activities; rather

2 Cf. Richard King, Orientalism and Religion: Postcolonial Theory, India, and 'The Mystic East', London/New York 1999; S.N. Balagangadhara, The Heathen in His Blindness: Asia, the West and the Dynamic of Religion, Leiden 2005; Geoffrey A. Oddie, 'Orientalism' and British Protestant Missionary Constructions of India in the Nineteenth Century, in: South Asia: Journal of South Asian Studies 17 (1994) 2, 27-42; GAURI Viswanathan, Outside the Fold: Conversion, Modernity and Belief, Princeton 1998.

3 Cf. Chandra Talpade Mohanty, Under Western Eyes: Feminist Scholarship and Colonial Discourse, in: Boundary 2: An International Journal of Literature and Culture, 12/3, 13/1 (Spring-Autumn, 1984), 333-358.

4 Anna Johnston, Missionary Writing and Empire, 1800-1860, Cambridge 2003, 39-44. 
that there are multiple meanings and understandings possible. It is the thrust of this paper that a postcolonial interrogation of archival space, more precisely of mission archives, might provide us a re-imagined methodological position into local Christian histories which were once viewed exclusively as Christian mission histories.

\section{Interrogating Archival Space}

"[...] historians can only really become historians or write history once they have been to the archive." ${ }^{5}$ This statement of Nicholas B. Dirks calls historians to have a living engagement with the archives which is the artefact of any history. He further argues that " $[\mathrm{t}]$ he archive is simultaneously the outcome of historical process and the very condition for the production of historical knowledge" ${ }^{\prime \prime}$. Thus, he does not only accentuate the importance of historicizing the archives but also to be cautious of and to interrogate knowledgeclaims' that are produced within a schematized archival space.

Historians of Christian missions largely depend upon the Mission archives when they endeavor to produce a history of Christianity in countries where Christianity has partially or mostly emerged due to the work of a Western Mission. But as Michel Foucault identifies, "[...] in our time, history is that which transforms documents into monuments."7 This has mostly, if not entirely, become true among the Church-historians in India. Their treatment of archival documents as monuments of Western Christian empires resulted in the production of Church-histories that are Eurocentric, male-dominated, and hegemonically tooled for reinforcing imperial asymmetries. Therefore, there is a need to revisit our treatment of Mission archives. In this paper, I attempt to historicize one particular mission archive- the Evangelical Lutheran Mission ${ }^{8}$ Archives, Hermannsburg (Germany) - as an exemplary case and argue that the Archives preserved the mission records for reference use as well as in ways that worked to monumentalize both history and its documents. The Mission archives reflect the categories and operations of the mission itself. The Mission

5 Nicholas B. Dirks, Annals of the Archive: Ethnographic Notes on the Sources of History, in: Brian Keith Axel (ed.), From the Margins: Historical Anthropology and Its Futures, Durham/London 2002, 47-65, 48 .

6 Ibd.

7 Michel Foucault, Archaeology of Knowledge, London 2002, 8.

8 The Evangelical Lutheran Mission Society (also called as Hermannsburg Mission Society) of Hermannsburg, founded in 1849 in the village Hermannsburg, Germany, began to work among the Telugus in Andhra Pradesh, South India, in 1864. 
produces, organizes, and maintains the discourses that become available as the primary texts of history. At the same time, I would like to introduce the different treatment of archival documents that is done in previous researches and demand a new approach, an approach which might even call for a move out of the already defined and schematically designed archival space.

"Historians for long have been convinced about the authority and authenticity of the archive, its evidentiary status, and its production of history's 'trutheffect:"' ${ }^{9}$ Nevertheless, some scholars, even whilst recognizing the importance of archives and archival research, have substantially critiqued the way in which the archive has been treated in such researches. ${ }^{10}$ Scholars dealing with questions related to gender, feminism and sexuality have particularly expressed a strong discomfort against the way the archive has been used and the failure to see the dangers and limitations of it. They have argued that the archive has been worked a sign of historical subjectivity and as the most important source of production and institutionalisation of knowledge. ${ }^{11}$ They have questioned the notions of 'truth' and 'authority' as reflected in the idiom of the archive, and its distorted representation of women and sexuality. Such attempts also have led to ponder an alternative to deal with such problems. ${ }^{12}$ Hence, they argue for a reading of the archives between the lines in order to see the silences around sexuality and gender. There is also a demand among these scholars for the use of alternative archives, such as archives of feelings, emotion, memory and so on. ${ }^{13}$

9 Charu Gupta, Archives and Sexuality: Vignettes from Colonial North India, in: IDEM (ed.), Gendering Colonial India: Reforms, Print, Caste and Communalism, New Delhi 2012, 317-343, 317 .

10 Cf. Jacques Derrida, Archive Fever: A Freudian Impression, translated by EriC Prenowitz, Chicago 1995; Michel Foucault, The Order of Things: An Archaeology of the Human Sciences, New York 1973; Dirks, Annals.

11 Cf. Helen Freshwater, The Allure of the Archive, in: Poetics Today 24 (2003), 729-756; Anjali Arondekar, Without a Trace: Sexuality and the Colonial Archive, in: Journal of the History of Sexuality 14 (2005) 1-2, 10-27; SALONI MATHUR, History and Anthropology in South Asia: Rethinking Archive, in: Annual Review of Anthropology 29 (2000), 89-106; Antoinette Burton, Dwelling in the Archive: Women Writing House, Home, and History in Late Colonial India, New York 2003.

12 Cf. Mathur, History, 93.

13 Cf. Ann Cvetkovich, An Archive of Feelings: Trauma, Sexuality and Lesbian Public Cultures, Durham 2003. 
In his report of 1980, Ernst Seebaß, the former Manager of ELM, writes that in the year 1959 he began to collect and organize the historical documents related to the Hermannsburg Mission and the ELM. ${ }^{14}$ Most of these documents, namely letters, reports, sermons, memoirs, and similar materials, were kept in the ancillary room of the Mission House as the private and confidential property of the Mission. ${ }^{15}$ Seebaß started to organize and classify them in a 'systematic' order. This undertaking was considered by the Mission as a pioneering work towards the establishment and development of the Archives. ${ }^{16}$ As he notes in his report of 1980 , he initiated this task to make the invaluable documents and reports of the missionaries available for those who are interested in the Mission and its overseas partners. ${ }^{17}$ After the classification, these documents were brought to the attic floor of the library building and were taken care of by Diether Münch as an 'archivist.'18 As the library started to expand, the archival documents needed to move out. ${ }^{19}$ Eventually, all these documents were moved to a new building that is today the Archives of the ELM, the exemplary location of this paper.

In spite of being listed among the Archives in Lower Saxony on the database internet page of "Archivportal Niedersachsen", ${ }^{20}$ the ELM Archive is not easily accessible to the 'public'. Its physical location in the very corner of a small village, Hermannsburg, tells us something about the mission 'conspiracy'. Until

14 Ernst Seebaß, Missionsbibliothek und Missionsarchiv unter einem Dach: Ein Einführungsbericht zum 7. Mai 1980, Typewritten in 1980 and bound together with a lecture by the same author entitled, "Zur Geschichte des Hermannsburger Missionsseminars: Zeichen und Zeiten".

15 Hartwig F. Harms, Die Missionsanstalt und das Ev.-luth. Missionswerk in Deutschland seit 1959, in: ERnSt-August LüdEMANN (ed.), Vision: Gemeinde weltweit: 150 Jahre Hermannsburger Mission und Ev.-luth. Missionswerk in Niedersachsen, Hermannsburg 2000, 127-232, 203.

16 Нмв 1984, 128-129.

17 Cf. SеЕваß, Missionsbibliothek.

18 Diether Münch was the first appointed 'archivist' of the ELM Archive, though was not a trained in archival science but a theologian. He was followed by a trained archivist, Andreas Weber in 1999. In the year 2001 Weber left the archives to be a teacher in a school. Between 2001 and 2003 the Archive was without any archivist and in 2003 Rainer Allmann, a trained archivist, took over the responsibilities of the Archive. Since 2011 the archive is part of the Missionsseminar Hermannsburg which is since October 2012 replaced by the Fachhochschule für Interkulturelle Theologie (FIT). Interview with Rainer Allmann, the archivist, via e-mails dated 21.12.2012 and 27.12.2012.

19 Cf. Harms, Missionsanstalt, 203.

20 Cf. http://www.archivportal.niedersachsen.de. 
recent years, it was a closed corner for anyone who was not directly related to the Mission. Even today the institutional affiliation of the researcher matters a lot in obtaining entry to this archive. Thus, it becomes clear that the archive preserves records necessary for the maintaining of a conspiracy and this conspiracy relies heavily on the institutional relations of the Mission with archival documents. To enter the archive, for someone who has a different perspective than the 'Mission-friends', this is an act of entering into the schematized world of the Mission.

The researcher needs to undergo a long process of negotiation, and needs to agree to numerous conditions. ${ }^{21}$ The archivist decides on-site about access to the documents, based on the assumption that he understands the researcher's needs. Thus, the sheer effort and energy that the researcher puts into finding references for the subject of his/her interest has to be ultimately accredited by the archivist. In the case of 'women' as subject the archivist obviously recommends the folder that claims to contain 'all' documents related to 'the Hermannsburger Frauenmission' (Hermannsburg Women's Mission). Hence, it is institutionally assumed that the subject 'women' per se is absent in any documents other than this folder. In order to confront this assumption, it becomes obvious that there is a need to read the archives against its classification systems. Finding historical sources on 'women' under a varieties of subjects such as education, health, welfare, motherhood, director's reports, sermons, male-missionary reports, salary slips, and even miscellaneous becomes important. For example, the 'native' women were not only the subjects of 'Women Mission' but they were also of missionary programs, or inquiries of education, health, sexuality, motherhood etc.

21 One needs to make an undersigned contract with the Evangelical Lutheran Mission in Lower Saxony while undertaking a research at the archives. This contract paper between the research and the Mission contains important regulations that the researcher need to subscribe to. As the contract indicates, "Our archive is a relatively small one; it is being gradually worked through by our archivist and is mainly run in a conventional way [...]" (emphasis added). To quote some selected lines from the contract: "Your research in our archives is subject to confidentiality [...]. For our records [...] we request/obtain a copy of your elaborated paper as far as essential parts of our archives have been used for it [...] Any publishing of the materials from our archive other than the general content-related publishing is only subject to our strict authorisation = issuance of the rights of use as per "Gesetz über Urheberrecht und verwandte Schutzrechte." Contract Paper between Gladson Jathanna, the researcher, and Detlef Kohr, the Manager of ELM, dated 17.12.2009. 
The Mission archival space has the powerful potential to evoke the gendered face of European missionary discourse. The following example demonstrates this fact well:

On July 1oth 2006 the archivist of ELM Archives receives a letter from Klaus Schrader, a retired pastor from Neuendettelsau. ${ }^{22}$ In his letter, Schrader thanks the archivist for making the archival materials available to him to write his lecture entitled, "Aus dem Steigerwald in Gottes Mission-Johann Wörrlein in Indien" (trans. from the Steigerwald in God's Mission-Johann Wörrlein in India), which was presented at a Mission-festival (Missionsfest) in Hellmitzheim on July gth 2006. Along with the letter he sends a copy of his lecture, which today is part of the Archives. This seven-page lecture recalls the life and work of missionary Johann Wörrlein and invites the contemporary Christian community in Germany to be proud of its 'heroes' in the mission history. ${ }^{23}$ Schrader uses a number of archival documents as monuments of life and work of this 'hero' in mission. Interestingly enough, the lecture does not completely forget the association of the missionary's wife with the mission. He writes, partially reciting Wörrlein from his Vierzig Jahre in Indien, "on 20 October 1873 there arrived a steamer 'Eldorado' in Madras—and with that his bride, Elisabeth v[on] Mengershausen, a daughter of a pastor. Soon she became his eager helpmeet in the Mission work and at Home."24 With but one sentence the lecture reaffirms the year-old Western belief that the wife of a missionary is called to be a 'helpmeet' of her husband both in the missionwork and at home. This way, the Mission Archive preserved the mission records for reference as well as for use in ways that worked to monumentalize both history and its documents.

Such documentary evidences, though exemplary in choice, show that the archival process is not only a historical exercise but also a contemporary practice of reinforcing the structural gendered differences in history. Such cases are powerful reminders that the social worlds of missionary power, like that of mission history, have been always male-dominated even till today. Hence, it is right to say that the mission archives contain the memory of gendered imagination of the missionaries in all its complexity and instability. Because such

22 Letter from Klaus Schrader to Rainer Allmann, dated July 1oth 2006. Persönliche AktenJohann Wörrlein, ELM Archive Folder 1112.

23 Cf. Klaus Schrader, Aus dem Steigerwald in Gottes Mission-Johann Wörrlein in Indien: A Lecture Given in the Dekanatsmissionsfest in Hellmitzen on 9 July 2006, 1. Persönliche Akten-Johann Wörrlein, ELM Archive Folder 1112.

24 Op.cit., 5. 
archives are important 'contact zones' with the missionary past, they produce a variety of cultural encounters which are, in most cases, gendered.

\section{Mission Archives between 'Commission' and Omission: Negotiating Archival Gap}

Addressing the 'gap' within the missiological discourse, Marion Grau recognizes that "the many glaring gaps, wounds, and omissions of encounters in mission call out to be minded, remembered, lamented, and transformed"25. One of the manifestations of such 'gap', she states, is "the absence in dominant accounts of mission history of the contribution of women, as missionaries and as local interlocutors and the implied limitations of what is considered 'mission"'26. One way of dealing with this problem, Grau argues, is to identify the archives as "the patchy canvas of sources"27. It helps us to spot the obscuring and omitting of vital oral discourses in the missionary narrative. Thus a Church-historian is invited to read the oral epics of the native Indians against the grain of missionary archival discourse. This has to challenge the researcher to take this exercise further and identify how a distorted history of women is produced due to intentionally and institutionally neglect of such archival gaps.

Lisa Curtis-Wendlandt, in her article "Corporal Punishment and Moral Reform at Hermannsburg Mission," takes up an important issue concerning the treatment of archival documents by the historians. Taking the example of the life of Carl Strehlow, a missionary of the Hermannsburg Mission to Central Australia during 1894-1922, she brings a critical factor to light, namely, the beating practice of the missionaries. She argues, "The abundant archival records of their lives provide clear and convincing evidence that during this time, Carl Strehlow, like many of his missionary colleagues, picked up the cane and used it on the Aborigines at the mission. But this is rarely mentioned."28 She further complains that even the award-winning biographies on missionaries deliberately omit any reference to such practices. ${ }^{29}$ Omission in missionary discourse, thus, becomes a crucial issue.

\footnotetext{
25 Marion Grau, Rethinking Mission in the Postcolony: Salvation, Society and Subversion, New York 2011, 18.

26 Ibd.

27 Ibd.

28 Lisa Curtis-Wendlandt, Corporal Punishment and Moral Reform at Hermannsburg Mission, in: History Australia: Journal of the Australian Historical Research 7 (2010), 1-17, 1.

29 Cf. op.cit., $1-2$.
} 
A Missionary writes in his report,

Our brothers in foreign lands are striving hard carrying the Great Commission of our Lord Jesus Christ, 'therefore go, and make disciples of all nations, baptizing them in the name of the Father and of the Son and of the Holy Spirit teaching them to observe all things that I commanded you.' We need to pray earnestly for them that they may not fail short in this mission of God. ${ }^{30}$

Abiding to the biblical and Christian concept of "Great Commission," the European missionaries believed in an expansionist missiological 'calling. It was not particular only to the Hermannsburg missionaries. An expansionist missiological belief was an integral part of the missionary movement right from its beginning. William Carey (1761-1834), who is regarded as one of the architects of the modern missionary movement, was convinced that the "New Testament command to preach the gospel to every creature was as binding upon the Christians of all times as it was upon the apostles"31. His faith legitimized the expansion of Christian faith and norms to different corners of the world. Gustav Warneck (1834-1910), who has been characterized as the "founder not only of the German missiology but also of the Protestants," and as the "educator of the church for mission" 32 , states, "I understand by missions the whole operation of Christendom directed towards the planting and organization of the Christian church among non-Christians." ${ }^{33}$ Missionaries believed that in order to be 'faithful' to their commitment to the "Great Commission", it was necessary and obvious to follow a policy of "omission" from their practice all that did not subscribe to the "Commission". Missionaries made it a point to 'omit' everything that was 'against' their beliefs from the missionary discourse. Hence, the Mission archive produces an intentional and institutional 'gap', which makes the subaltern voices feeble and sometimes even unheard.

30 Visitation des Arbeitsfeldes durch die Heimatleitung, Missionsdirector Egmont Harms, 1892 A.I. 30 A.

31 William Carey, An Enquiry into Obligations of the Christians to Use Means for the Conversion of the Heathens, Leicester 1792, 13 .

32 HANS KASDORF, Gustav Warnecks missiologisches Erbe: Eine biographisch-historische Untersuchung, Gießen 1990, iii.

33 Keith Clements, Faith on the Frontier: A Life of J.H. Oldham, Edinburgh 1999, 59-6o. 


\section{Reading Archives: Shocking Adventure}

Mrinalini Sebastian describes her reading experiences of mission archives as a voyeuristic thrill. ${ }^{34}$ For Nicholas Dirks, reading archives was "a shocking experience" 35 . Reading archives can thus be called "a shocking adventure" because the documents in the archives are not meant for our eyes, but were originally written for friends and patrons of a particular missionary society. They generally contain narratives that illustrate the certainty of the writer in the Christian faith and also his conviction in the superiority of that faith, constructing an imaginary image of the natives. The native, as a reader, sometimes locates in these pages his own ancestors and the beginnings of the community to which he belongs. And based on these narratives the history of that particular community is constructed. However, such a construction of historiographies has, very often, ended up being both mission-society-centered and male-centered, constructing one more saga of European Christian triumphalism over the Indian natives. Such imaginary construction is partially due to the way of handling the mission-archives by the historians. Many historians and cultural scientists have not taken into serious consideration intentionally omitted texts in the mission archives and institutionally forgotten actors in the mission field.

An adventurous engagement with the mission archives calls us for a reimagination of mission historiographies. It helps to understand the social matrix in which the missionaries worked and also the nature of the encounter between the missionaries and the natives. Such an engagement leads the researcher to interrogate, specifically, the gendered nature of the mission as well as the mission archive. It raises a set of daring questions which, at times, might produce shocking answers. For example, what role did missionary women and the native Christian women play in the encounter between missionaries and other native women? Why have the women very often become a passive focus of Mission history? Is it because women do not have a voice in the archives, or are they not heard enough? To paraphrase Gayatri Spivak: can these subalterns speak through archival process? ${ }^{36}$ And to probe further in a different direction, do these subalterns refuse to speak? Or do the historians refuse to listen to them? What happened or happens between women speaking and men

34 Cf. Mrinalini Sebastian, Reading Archives from a Postcolonial Feminist Perspective: "Native" Bible Women and the Missionary Ideal, in: JFSR 19 (2003), 5-25, 5.

35 DiRKs, Annals, 48.

36 Cf. Gayatri Chakravorty Spivak, Can the Subaltern Speak?, in: Cary Nelson/ LAWrence Grossberg (eds.), Marxism and the Interpretation of Culture, Basingstoke 1988, 271-316, 308 . 
listening in a process of historicizing? These questions would certainly lead a historian to gain a different perspective on the missionary enterprise, a perspective shaped by questions rooted in the subjectivity of women.

Jacques Derrida coined the term "archive fever"37. This term captures the anxieties about the contamination of archival history that has generated debates about the future of history in the last two decades of the twentieth century.38 The postmodern modes of analysis of history demanded the need to move out of the archive-based research, to use extra-archival sources and to produce history in a kind of popular culture. This movement opened up new frontiers for the production of history. ${ }^{39}$ However, these movements did not go uncriticized. Such critics, especially the historians of British Empire and colonialism, often called for a 'return to the archive'40. These conflicts have led the historians to find possibilities to respect the traditional archives on the one hand and on the other, to be critical about its distortions, skeptical about its truth-claims and suspicious about its collaborations with power agencies. ${ }^{41}$

There is a tendency among the mission/church-historians to undermine any historical research and exploration which is not done within the premise of the 'archives' 42 As argued above, it is indeed in the mission archives where historical narrations of the Christian past take shape. Mission archives do provide us with an enormous amount of sources upon which the history of Christianity is to be built, but not entirely. However, this must not lead the historians to overlook the panoptical space of mission archives. ${ }^{43}$ Michel Foucault uses the idea of panopticon as a metaphor for technologies of modern power. He argues that it is a model where the prison, the asylum and the hospital embody the same will to omnipotence, and to disciplinary formation that the archive

37 JaCQues Derrida, Archive Fever, Chicago 1995.

$3^{8}$ Cf. op.cit., $15^{-16 .}$

39 Cf. Paul J. Voss/Marta L. Werner, Toward a Poetics of the Archive, in: Studies in the Literary Imagination (special issue: The Poetics of the Archive), 32 (1999), i-viii, i.

40 Carolyn Steedman, Something She Called a Fever: Michelet, Derrida and Dust, in: AHR 106 (2001) 1159-1180.

41 Cf. op.cit., 1163.

42 Cf. Andrew F. WAlls, Eusebius Tries Again: The Task of Reconceiving and Re-visioning the Study of Christian History, in: Wilbert R. Shenk (ed.), Enlarging the Story: Perspectives on Writing World Christian History, New York 2002, 1-21.

43 The panopticon is originally a Benthamite ideal: a blueprint for the modern prison and later the workhouse. For further details, cf. BuRTon, Archive, 140-143. 
also does. ${ }^{44}$ This claim has been taken further by some scholars to demonstrate that researches, especially on race, class and gender, have to take the panoptical space of the archive into serious consideration. ${ }^{45}$ Though these scholars have not denied the relevance of archive for the production and reproduction of history, they call for a move beyond the institutional archival space and the recognition of the capacity and resourcefulness of extra-archival sources.

Identifying the importance and limitations of archival space, thus, becomes an important starting point when reading the mission archives in parallel to the extra-archival documents. The recognition that the mission archives are contaminated and distorted must lead us to explore different possibilities of breaking the archival walls. Listening to the silences of gendered 'agents' of the mission within the archives is one such possibility to break those walls that are constructed by the male-centred mission agency. Discerning the native voices in oral forms such as native art, music, dances etc., and thus identifying these sources as authentic historical documents is also an important tool to break the dominant 'archival' walls and to re-imagine its wider space. This demands the necessity to extend the archival space by considering the 'extra-archival' documents as 'archival' since they preserve untold stories of subalterns for centuries.

\section{Bibliography}

\section{Primary Sources}

Carey, William, An Enquiry into Obligations of the Christians to Use Means for the Conversion of the Heathens, Leicester 1792.

Letter from Klaus Schrader to Rainer Allmann, dated July 10th 2006. Persönliche Akten-Johann Wörrlein, ELM Archive Folder 1112.

Schrader, Klaus, Aus dem Steigerwald in Gottes Mission-Johann Wörrlein in Indien: A Lecture Given in the Dekanatsmissionsfest in Hellmitzen on 9 July 2006, 1. Persönliche Akten-Johann Wörrlein, ELM Archive Folder 1112.

Seebaß, Ernst, Missionsbibliothek und Missionsarchiv unter einem Dach: Ein Einführungsbericht zum 7. Mai 1980, Typewritten in 1980 and bound together

44 Cf. Michel Foucault, The Birth of Clinic: An Archaeology of Medical Perception, New York 1973; Michel Foucault, Discipline and Punish: The Birth of the Prison, New York 1977.

45 Cf. Edward W. Said, Orientalism, New York 1978; Gayatri Chakravorty Spivak, The Rani of Sirmur: An Essay in Reading the Archives, in: HTh 24 (1985), 247-272; Dip ESH Chakrabarthy, The Death of History? Historical Consciousness and the Culture of Late Capitalism, in: Public Culture 4 (1992) 2, 47-65. 
with a lecture by the same author entitled, "Zur Geschichte des Hermannsburger Missionsseminars: Zeichen und Zeiten".

Visitation des Arbeitsfeldes durch die Heimatleitung, Missionsdirector Egmont Harms, 1892 A.I. 30 A.

http://www.archivportal.niedersachsen.de.

\section{Literature}

Arondekar, ANJALI, Without a Trace: Sexuality and the Colonial Archive, in: Journal of the History of Sexuality 14 (2005), 10-27.

Balagangadhara, S.N., The Heathen in His Blindness: Asia, the West and the Dynamic of Religion, Leiden 2005; Geoffrey A. OdDiE, 'Orientalism' and British Protestant Missionary Constructions of India in the Nineteenth Century, in: South Asia: Journal of South Asian Studies 17 (1994) 2, 27-53.

Burton, Antoinette, Dwelling in the Archive: Women Writing House, Home, and History in Late Colonial India, New York 2003.

Chakrabarthy, Dipesh, The Death of History? Historical Consciousness and the Culture of Late Capitalism, in: Public Culture 4 (1992) 2, 47-65.

Clements, Keith, Faith on the Frontier: A Life of J.H. Oldham, Edinburgh 1999.

Curtis-Wendlandt, Lisa, Corporal Punishment and Moral Reform at Hermannsburg Mission, in: History Australia: Journal of the Australian Historical Research 7 (2010), 1-17.

Cvetrovich, Ann, An Archive of Feelings: Trauma, Sexuality and Lesbian Public Cultures, Durham 2003.

Derrida, JACQues, Archive Fever: A Freudian Impression, translated by ERIC Prenowitz, Chicago 1995 .

Dirks, Nicholas B., Annals of the Archive: Ethnographic Notes on the Sources of History, in: Brian Keith Axel (ed.), From the Margins: Historical Anthropology and Its Futures, Durham/London 2002, 47-65.

Foucault, Michel, The Birth of Clinic: An Archaeology of Medical Perception, New York 1973 .

Foucault, Michel, The Order of Things: An Archaeology of the Human Sciences, New York 1973.

Foucault, Michel, Discipline and Punish: The Birth of the Prison, New York 1977.

Foucault, Michel, Archaeology of Knowledge, London 2002.

Freshwater, Helen, The Allure of the Archive, in: Poetics Today 24 (2003), 729-756.

Grau, Marion, Rethinking Mission in the Postcolony: Salvation, Society and Subversion, New York 2011.

Gupta, Charu, Archives and Sexuality: Vignettes from Colonial North India, in: EADEM (ed.), Gendering Colonial India: Reforms, Print, Caste and Communalism, New Delhi 2012, 317-343. 
Harms, Hartwig F., Die Missionsanstalt und das Ev.-luth. Missionswerk in Deutschland seit 1959, in: ERnST-August LüDEMANN (ed.), Vision: Gemeinde weltweit: 150 Jahre Hermannsburger Mission und Ev.-luth. Missionswerk in Niedersachsen, Hermannsburg 2000, 127-232.

Johnston, Anna, Missionary Writing and Empire, 1800-186o, Cambridge 2003.

KASDORF, HANS, Gustav Warnecks missiologisches Erbe: Eine biographischhistorische Untersuchung, Gießen 1990.

KIng, Richard, Orientalism and Religion: Postcolonial Theory, India, and 'The Mystic East', London/New York 1999.

Mathur, SAloni, History and Anthropology in South Asia: Rethinking Archive, in: Annual Review of Anthropology 29 (2000), 89-106.

Mohanty, Chandra Talpade, Under Western Eyes: Feminist Scholarship and Colonial Discourse, in: Boundary 2, 12/3, 13/1 (Spring-Autumn, 1984), 333-358.

Mundadan, A. Mathias, The Changing Task of Christian History: A View at the Onset of the Third Millennium, in: Wilbert R. Shenk (ed.), Enlarging the Story: Perspectives on Writing World Christian History, New York 2002, 22-53.

SAID, EDWARD W., Orientalism, New York 1978.

Sebastian, Mrinalini, Reading Archives from a Postcolonial Feminist Perspective: "Native" Bible Women and the Missionary Ideal, in: JFSR 19 (2003), 5-25.

Spivak, Gayatri Chakravorty, The Rani of Sirmur: An Essay in Reading the Archives, in: HTh 24 (1985), 247-272.

Spivak, Gayatri Chakravorty, Can the Subaltern Speak?, in: Cary Nelson/ LAWrence Grossberg (eds.), Marxism and the Interpretation of Culture, Basingstoke 1988, 271-316.

Steedman, Carolyn, Something She Called a Fever: Michelet, Derrida and Dust, in: AHR 106 (2001), 1159-1180.

Viswanat Han, Gauri, Outside the Fold: Conversion, Modernity and Belief, Princeton 1998.

Voss, Paul J./Marta L. Werner, Toward a Poetics of the Archive, in: Studies in the Literary Imagination (special issue: The Poetics of the Archive), 32 (1999), i-viii.

WALls, Andrew F., Eusebius Tries Again: The Task of Reconceiving and Re-visioning the Study of Christian History, in: Wilbert R. Shenk (ed.), Enlarging the Story: Perspectives on Writing World Christian History, New York 2002, 1-21. 